Henryk Dzwigol,

Ph.D., Professor, Silesian University of Technology, Poland

\title{
INNOVATION IN MARKETING RESEARCH: QUANTITATIVE AND QUALITATIVE ANALYSIS
}

Abstract. This article focuses on the triangulation of research methods and techniques in the discussion on the evaluation of marketing research. Research traditions in marketing can be referred to the division of research methodologies, according to which the methods of conceptual, theoretical, empirical and formal research is distinguished, based on the use of quantitative methods, mathematical and statistical models. In scientific research on marketing, conceptual methods (i.e. heuristic or creative methods) are used, with a primary focus on the analysis of qualitative aspects of the studied processes, thus making little reference to empirics. The methodology of empirical research in marketing is used to a great extent. It allows developing empirical models, thus making it possible to recognize, e.g. actually implemented models of marketing strategies that may be consistent with or deviate from the theoretical models. However, it should be noted that empirical models do not always have implementation properties, as they most often refer to the present or past reality. Nevertheless, these models may be subject to benchmarking. Moreover, they serve to make conceptual models more probable. For the further development of marketing, it becomes essential to increase the scope of application of formal research methodologies as well. The analysis of the literature indicates the need for an in-depth diagnosis of combined methods in the research process in the broader context of management sciences. The aim of the article is therefore expressed as a research problem in the form of the following question: Is methodological triangulation a prerequisite for research processes in the management sciences? The research results presented in this article are a fragment of complex study on research methodology. Moreover, the conducted empirical research confirms and theoretically proves that methodological triangulation is a necessary condition in research processes. In contrast, verification of developed methods, models or procedures is an essential condition allowing to combine science and management practice, while methodological triangulation supports research processes. Concerning the preceding, the author recommends in the present article to make a scientific effort aimed at elaborating a tool, method or procedure to select proper research methods and techniques for the research process within the scope of management science, with a particular emphasis on factors determining the process quality.

Keywords: methods, research techniques, marketing research, triangulation, research methodology.

Introduction. Multidimensionally determined changes occurring in marketing research refer not only to research methods and techniques but also occur in the cross-section of the subject of study and results - the effects of research, as well as the conditions of carrying it out (Avila-Robinson and Wakabayashi 2018). Moreover, these changes force the current research processes to combine qualitative and quantitative methods (Quach et al. 2019; Gordon et al. 2018).

Triangulation is more and more often viewed as the use of a set of various methods so that to achieve coherent foundations for empirical inferencing (Kostera, 2003). Moreover, the selection of appropriate research methods and techniques for the research process is now becoming a challenge for researchers (Dzwigol, 2018; Dzwigol \& Dzwigol-Barosz, 2018). The purpose of this article is to determine the impact of combined quantitative and qualitative methods on the research process in marketing.

Literature Review. Research traditions in marketing can be referred to the division of research methodologies, according to which the methods of conceptual, theoretical, empirical and formal research is distinguished, based on the use of quantitative methods, mathematical and statistical models (Mazurek-Lopacinska, 2015). In scientific research on marketing, conceptual methods (i.e. heuristic or creative methods) are used. It with a primary focus on the analysis of qualitative aspects of the studied processes, thus making little reference to empirics (Quach et al. 2019) Theoretical models such as P. Drucker's business model, M. Porter's 5P model and H. Borden's marketing composition model

Cite as: Dzwigol, H. (2020). Innovation in Marketing Research: Quantitative and Qualitative Analysis. Marketing and Management of Innovations, 1, 128-135. http://doi.org/10.21272/mmi.2020.1-10 
should also be indicated. The methodology of empirical research in marketing is used to a great extent. It allows to develop practical models, thus making it possible to recognize, e.g. actually implemented models of marketing strategies that may be consistent with or deviate from the theoretical models (Gordon et al. 2018). However, it should be noted that empirical models do not always have implementation properties, as they most often refer to the present or past reality.

Nevertheless, these models may be subject to benchmarking. Moreover, they serve to make conceptual models more probable (Zabinski, 2006). For the further development of marketing, it becomes essential to increase the scope of application of formal research methodologies as well (Acharjya and Das, 2017).

Multidimensionally determined changes occurring in marketing research refer not only to research methods and techniques but also occur in the cross-section of the subject of study and results - the effects of research, as well as the conditions of carrying it out (Avila-Robinson and Wakabayashi 2018). It should be underlined that the subject and objects of study are gradually becoming more and more complex. Moreover, the influence of volatile and difficult-to-measure factors on the behaviour of market players also aggravates the difficulties in the interpretation of research results. On the other hand, changes in the conditions for conducting research involve creating artificial and natural health for experiments, as well as requirements for learning about psychophysical reactions (Cunningham and Wallraven, 2011). Besides, the development of applications of new technologies brings about an evolution in marketing research, with a shift from classical analysis to study based on new technologies and multiple disciplines (Quach et al. 2019). More and more increased expectations regarding the results of marketing research make it necessary, on the one hand, to deepen the cognitive sphere. In the other hand, to reach the emotional area, as well as to reduce the gap between the respondents' declarations and the buyers' behaviour and to separate reliable information about facts and events from information that disturbs the image.

The above indications directly urge, within the scope of the current research processes, to combine qualitative and quantitative methods (Dzwigol and Wolniak, 2018). It is due to the growth of the entity, the research object and the quality of the research process, which is determined by the continuity of changes imposed by the market, especially in management or marketing sciences. The use of a package of differentiated methods is gradually highlighted (Dzwigol et al. 2019) so that to achieve coherent foundations for empirical inferencing (Kostera, 2003), i.e. research triangulation.

In social sciences, it is a mistake to use only one research method appropriate for a given research subject in the conducted research.

M. Kostera points out that 'the choice is always a derivative of the research problem, that is, depending on what you want to investigate, you decide how to investigate it in the best way'. Relying on only one research method does not instil trust as to the conclusions of the work. Besides, if the research method used in the dissertation were to be based on a literature-related analysis, then the research work would be strictly theoretical. In order to make the research more credible, the so-called triangulation of research methods should be applied:

- to learn about the phenomenon in a broader perspective;

- to increase in the quality of the tests carried out;

- to reduce measurement errors.

Thus, the development of research methods in the sciences of management and marketing is directly related to scientific and technological progress in various aspects of economic activity (Boiko et al., 2019; Dalevska et al., 2019; Dzwigol, 2019; Dzwigol \& Wolniak, 2018; Kaminska, 2018; Kuzior et al., 2019; Kwilinski, 2018a, 2018b; Kwilinski et al., 2019; Pajak et al., 2016, 2017; Savchenko et al., 2019; Tkachenko et al., 2019; Vasylieva et al., 2018), including neuromarketing (Lim, 2018; Sebastian, 2014) 
and reflective management in communications (Bezchasnyi, 2018), which necessitates the use of new approaches to research and verification of its empirical data, one of which is triangulation.

Triangulation is often viewed as the use of a set of various methods so that to achieve coherence between cognition and conclusions. D. Campbell and D. Fiske (1959) were forefathers of viewing triangulation as a blend of diverse methods in one single research. In other words, triangulation means the application of two or more independent processes to measure a phenomenon to reduce the interpretative uncertainty of the results obtained from the tests (Webb et al. 1966). The core of triangulation is the employment of two or more methods, based on which one can compare achieved results and derive conclusions related to the employed methods (Stanczyk, 2016; Venkatesh et al., 2013). Combining qualitative and quantitative methods has been viewed as an example of best practice (Jick, 1979). Triangulation characterises, examines and analyses reality in many different dimensions; therefore, it is reasonable to use methods taken from two different sets. This approach to research is called: comprehensive, complementary or poly-methodical (Stanczyk, 2016).

Triangulation is well established in the area of research methodology, whereas this knowledge is essential for all future research intentions using this research procedure (Kostera, 2003). Today, the growing popularity of triangulation among researchers can be seen. Still, it is used with varying degrees of success in terms of its correct use and understanding, with the risk of misinterpretation (Thomas, 2017).

Methodology and research methods. Conclusions emerging from a concluded literature analysis dealing with the research methodology in management sciences showed a need to review combining methods as part of research processes. The following research questions were adopted in the article:

1. Is methodological triangulation a prerequisite for research processes?

2. Is it necessary to verify the developed methods, procedures or models in practice to make the research credible?

3. Does a researcher affect the combination of quantitative and qualitative methods in the research process?

4. The research processes supported by methodological triangulation?

5. As a result, defining a research problem, is it necessary to analyse qualitative and quantitative methods, to make them a preliminary selection?

6 . Is the verification of the developed methods, models and procedures a necessary condition for combining science and management practice?

In order to answer the research questions posed, the research was carried out using a questionnaire (October 2016 to April 2018).

The questionnaire was based on three parts:

1. Questions about the importance of approaches, methods and techniques, in a research process within of management science.

2. Questions related to the quality of the research process.

3. Demographics.

The structure of the questionnaire part involved both questions based on the 5-point Likert scale (strongly agree (5), agree (4), neither agree nor disagree (3), disagree (2), strongly disagree (1), concerning each of proposed assumptions) and open questions (Dzwigol, 2018).

Quantitative research (questionnaires) was directed to a target group consisting of management science theorists. The target group consisted of: 272 foreign universities units dealing with management sciences, 21,024 international academic staff connected to the management sciences, 93 polish universities units dealing with management sciences, 2,307 Polish academic staff related to the management sciences. 
Results. As a result of the research effort, 401 representatives of management science theorists were surveyed (Figure 1). The obtained results confirm the extensive literature research on research methodology, where it is noted that the use of numerous diverse methods in the research process allows for a comprehensive approach to the research problem and gives a complete picture of it.

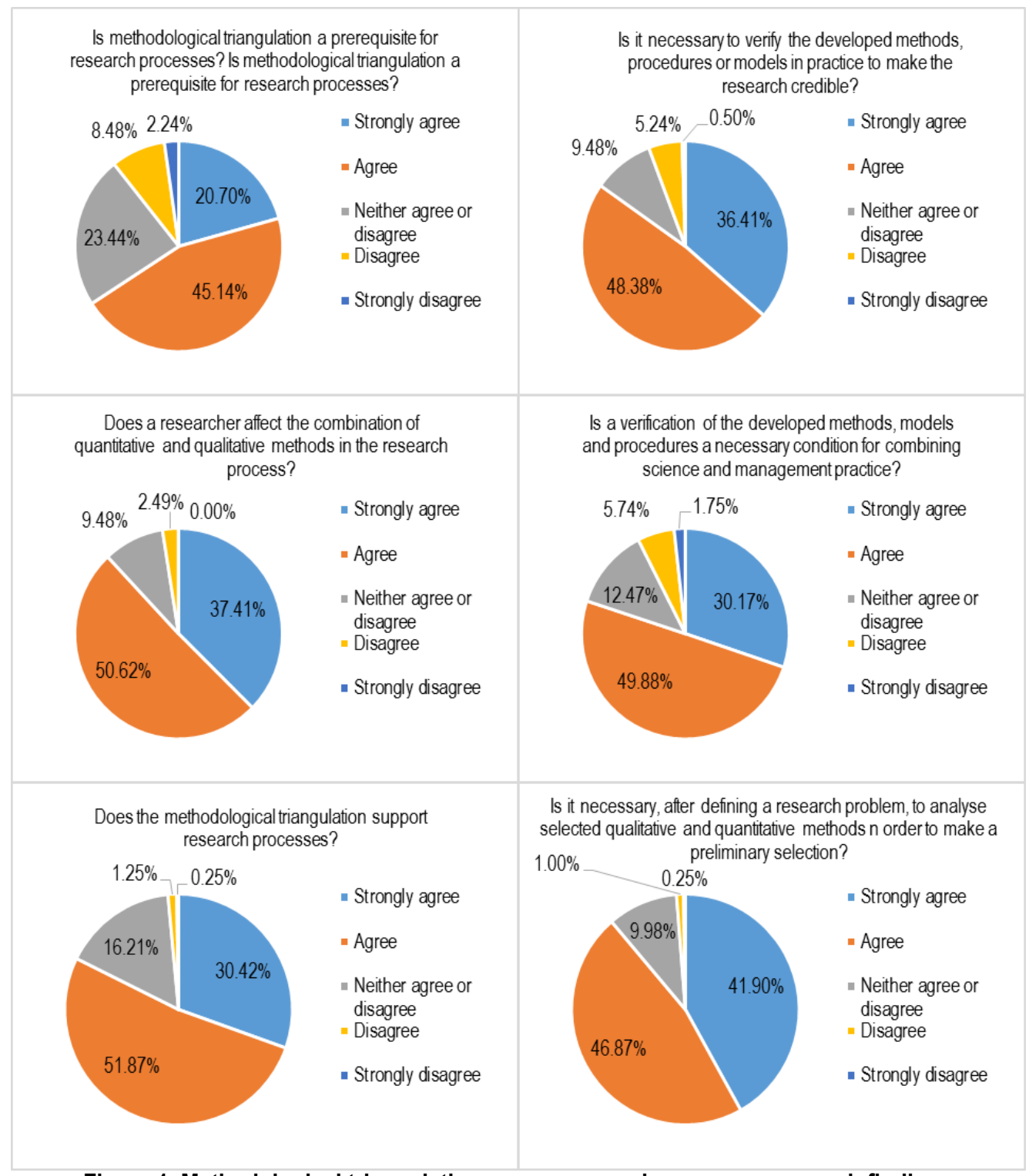

Figure 1. Methodological triangulation versus research process - research findings

Source: developed by the author. 
When analysing the obtained results, it can be clearly stated that once the research problem is formulated, it is necessary to analyse selected quantitative and qualitative methods with the aim of their preliminary selection (Dzwigol et al. 2019). The above thesis can also be confirmed in the subject-related literature, where it is often indicated that to fully and thoroughly diagnose a research problem, it is necessary to apply diverse research methods providing a comprehensive response to the posed question. Furthermore, the very development of modelling, heterogeneous cognitive processes of organisation management has an impact on the necessity to combine numerous approaches and methods. According to the said approach, it is necessary to put designed methods, procedures and models into practice to make the research more credible. It is also essential, before undertaking the research study, to analyse selected processes in terms of the character of ongoing research (Thomas 2017; O'Leary 2017).

The experts who completed the survey hold the opinion that combining qualitative and quantitative methods in research processes within the scope of management science significantly support the quality of the process itself, as well as make the research results credible. Moreover, the experts state that the division between qualitative and quantitative methods in the research-related practice is not always a clear one; it is not evident where to meet determined conditions, such as, e.g., an order of applying methods or maintaining objectivism in the research results. Furthermore, as it was emphasised by Professor K. Pajak (2010, p. 185 et seq.), qualitative research within management science should revolve around an extended analysis of a given phenomenon. The main emphasis is that unique research methods should encourage a better and more precise understanding of an analysed problem. Contrary to quantitative research, qualitative research is not particularly systematised. It lacks a quantitative approach, as statistical inference is not frequently employed there. In an ideal methodological situation, if a researcher wishes to discover or learn something, verify a posed hypothesis or a research question, then, in most cases, quantitative and qualitative methods complement each other.

Functions and applicability of both methods and their blends have been diverse, mainly depending on a research subject and research goals, as well as on a phase the research process is currently. Nonetheless, should the researcher's attention start evolving around discovering and/or learning (including interpreting) cause-and-effect relationships, or mechanisms governing functions and processes, their underlying conditions and further consequences, and around setting research hypotheses related to the said assumptions, then, it should be necessary to complement quantitative methods with (additional) qualitative ones?

Conclusions. The following paper aimed to determine the impact of the combined qualitative and quantitative methods on how research processes go. The analysis of domestic and foreign literature on triangulation, combined with research conclusions unquestionably indicates that:

- methodological triangulation is a prerequisite for research processes;

- in order to make the tests credible, it is necessary to verify the methods, procedures or models developed in practice;

- a researcher affects the combination of quantitative and qualitative methods in the research process;

- verification of the developed methods, models and procedures is a necessary condition for combining science and management practice;

- triangulation supports research processes.

The theses mentioned above have been confirmed by the study by A. Bryman (2006). Mixed research studies have been commonly used in just a few disciplines. In contrast, valuable subjectrelated works have been published mainly in the American papers when reviewing other subject-related research studies (by, among others, K. Niglas (2004), or S. Cisek (2010) one can conclude that mixed 
methods have already become a considerable element of the management sciences; the authors have underlined that their condition is not satisfactory.

Each type of integrating methodical approaches in marketing brings the synergy effect mentioned at the beginning. Thanks to the triangulation of methodological approaches, it is possible to collect data which allow shaping broad and deep knowledge at the same time. Such an approach minimizes the imperfections of both interpretative and positivist approaches - after all, there is no such thing as ideal methodology. However, it is worth bearing in mind that triangulation of methodological approaches is often complicated, time-consuming and costly. Applying an integrated method requires a plan based on pluralism, syncretism, i.e. constant compromise and balance between facts and values, knowledge and wisdom, rationality and emotional approach, idealism and materialism etc. (Johnson, Gray 2010, p. 90).

Concerning the preceding, it shall be recommended to carry out extensive research studies as to the application of methods and techniques in the research process, as well as to attempt to make a scientific effort aimed at elaborating a tool, practise or procedure to select proper research methods and techniques for the research process within the scope of management science, with a particular emphasis on factors determining the process quality.

\section{References}

Acharjya, D.P., \& Das, T.K. (2017). A framework for attribute selection in marketing using rough computing and formal concept analysis. IIMB management review, 292), 122-135. [Google Scholar] [CrossRef]

Avila-Robinson, A., \& Wakabayashi, N. (2018). Changes in the structures and directions of destination management and marketing research: A bibliometric mapping study, 2005-2016. Journal of Destination Marketing \& Management, 10, 101-111. [Google Scholar] [CrossRef]

Bezchasnyi, O. (2018). Reflexive coordination of communications in the construction of models for the development of an industrial enterprise. Virtual Economics, 1(1), 66-83. [Google Scholar] [CrossRef

Bryman, A. (2006). Integrating quantitative and qualitative research: How is it done? Qualitative research, 6(1), 97-113. [Google Scholar] [CrossRef]

Boiko, V., Misiuk, M., Kwilinski, A., \& Boiko, L. (2019). Competitive advantages of wholesale markets of agricultural products as a type of entrepreneurial activity: the experience of Ukraine and Poland. Economic Annals-XXI,68. [Google Scholar] [CrossRef]

Campbell, D. T., \& Fiske, D. W. (1959). Convergent and discriminant validation by the multitrait-multimethod matrix. Psychological bulletin, 56(2), 81-105. [Google Scholar] [CrossRef]

Chlipala, P. (2014). Triangulacja podejść metodologicznych w badaniach naukowych z dziedziny marketingu. Prace naukowe Uniwersytetu Ekonomicznego we Wroclawiu, 336, 39-48. [Google Scholar]

Cisek, S. (2010). «Metodologia mieszana» w badaniach nauki o informacji i bibliotekoznawstwie. In Biblioteki, informacja, ksiazka: interdyscyplinarne badania i praktyka w XXI wieku (ePublikacje Instytutu Informacji Naukowej i Bibliotekoznawstwa, nr 7) (pp. 88-94). Instytut Informacji Naukowej i Bibliotekoznawstwa, Uniwersytet Jagiellonski. [Google Scholar]

Cunningham, D.W., \& Wallraven, C. (2011). Experimental design: From user studies to psychophysics. CRC Press. [Google Scholar]

Dalevska, N., Khobta, V., Kwilinski, A., \& Kravchenko, S. (2019). A model for estimating social and economic indicators of sustainable development. Entrepreneurship and Sustainability Issues, 64), 1839-1860. [Google Scholar] [CrossRef]

Denizm, N. K. (1978). Sociological Methods: A Sourcebook(2nd ed.). New York: McGraw-Hill.

Dzwigol, H. (2018). Wspolczesne procesy badawcze w naukach o zarzadzaniu. Uwarunkowania metodyczne i metodologiczne. Warszawa: PWN [in Polish]

Dzwigol, H. (2019). Research methods and techniques in new management trends: research results. Virtual Economics, 2(1), 31-48. [Google Scholar]

Dzwigol, H., \& Dzwigol-Barosz, M. (2018). Scientific Research Methodology in Management Sciences. Financial and Credit Activity: Problems of Theory and Practice, 2(25), 424-437. [CrossRef]

Dzwigol, H.; \& Wolniak, R. (2018). Controlling w procesie zarzadzania chemicznym przedsiębiorstwem produkcyjnym. Przemys/ Chemiczny, 977). [CrossRef]

Dzwigol, H., Dzwigol-Barosz, M., Zhyvko, Z., Miśkiewicz, R., \& Pushak, H. (2019) Evaluation of the energy security as a component of national security of the country. Journal of Security and Sustainability Issues, 8(3). [Google Scholar] [CrossRef]

Dzwigol, H., Aleinikova, O., Umanska, Y., Shmygol, N., \& Pushak, Y. (2019). An entrepreneurship model for assessing the 
investment attractiveness of regions. Journal of Entrepreneurship Education. [Google Scholar]

Gordon, R., Dibb S., Magee, C., Cooper, P., \& Waitt, G. (2018). Empirically testing the concept of value-in-behavior and its relevance for social marketing. Journal of Business Research, 82, 56-67, [Google Scholar] [CrossRef]

Greene, J.C., Caracelli, V.J., \& Graham, W.F., (1989). Toward a conceptual framework for mixed-method evaluation designs. Educational evaluation and policy analysis, 11(3), 255-274. [Google Scholar] [CrossRef]

Jack, E. P., \& Raturi, A. S. (2006). Lessons learned from methodological triangulation in management research. Management Research News. [Google Scholar] [CrossRef]

Jick, T. D. (1979). Mixing qualitative and quantitative methods: Triangulation in action. Administrative science quarterly, 24(4), 602-611. [Google Scholar] [CrossRef]

Johnson, B., \& Gray, R., (2010). A history of philosophical and theoretical issues for mixed methods research. Sage handbook of mixed methods in social and behavioral research, 2, 69-94. [CrossRef]

Kaminska, B. (2018). Iterative signal processing in anticipatory management of industrial enterprise development. Virtual Economics, 1(1), 53-65. [Google Scholar] [CrossRef]

Konecki, K. (2000). Studia z metodologii badan jakosciowych. Teoria ugruntowania. Wydawnictwo Naukowe PWN, Warszawa. [Google Scholar]

Kostera, M. (2003). Antropologia organizacji: Metodologia badań terenowych, Wydawnictwo Naukowe PWN, Warszawa.

Kuzior, A., Kwilinski, A., \& Tkachenko, V. (2019). Sustainable development of organizations based on the combinatorial model of artificial intelligence. Entrepreneurship and Sustainability Issues, 72), 1353-1376. [Google Scholar] [CrossRef]

Kwilinski, A. (2018a). Mechanism of modernization of industrial sphere of industrial enterprise in accordance with requirements of the information economy. Marketing and Management of Innovations, 4, 116-128. [Google Scholar] [CrossRef] Kwilinski, A. (2018b). Mechanism of formation of industrial enterprise development strategy in the information economy. Virtual Economics, 1(1), 7-25. [Google Scholar] [CrossRef]

Kwilinski, A., Pajak, K., Halachenko, O., Vasylchak, S., Pushak, Y., \& Kuzior, P. (2019). Marketing tools for improving enterprise performance in the context of social and economic security of the state: innovative approaches to assessment. Marketing and Management of Innovations, 4, 172-181. [Google Scholar] [CrossRef]

Labarca, C. (2017). Qualitative Research for beginners. Venezuela: Maracaibo.

Lim, W. M. (2018). Demystifying neuromarketing. Journal of Business Research, 91, 205-220. [Google Scholar] [CrossRef]

Niglas, K. (2004). The combined use of qualitative and quantitative methods in educational research. Tallinna Pedagoogikaülikooli Akadeemiline Raamatukogu.

O'Leary, Z. (2017). The essential guide to doing your research project. Sage. [Google Scholar]

Pajak, K. (2010). Rozwoj lokalny jako kategoria ekonomiczna [Local development as an economic category]. In A. Grzelak \& K. Pajak (Eds.), Nowe trendy w metodologii nauk ekonomicznych [New trends in the methodology of economic sciences] (pp. 185215). Poznan: Wydawnictwo Uniwersytetu Ekonomicznego w Poznaniu [in Polish].

Pajak, K., Kaminska, B., \& Kvilinskyi, O. (2016). Modern trends of financial sector development under the virtual regionalization conditions. Financial and credit activity: problems of theory and practice, 2(21), 204-217. [Google Scholar] [CrossRef]

Pajak, K., Kvilinskyi, O., Fasiecka, O., \& Miskiewicz, R. (2017). Energy security in regional policy in Wielkopolska region of Poland. Economia i Srodowisko. [Google Scholar]

Patton, M.Q. (2002). Qualitative research and evaluation methods: Integrating theory and practice. Sage Publications. [Google Scholar]

Rodina, O., Savchenko, T., Basiurkina, N., \& Kwilinski, A. (2019). Improvement of the assessment methods of product competitiveness of the specialized poultry enterprises. Management Theory and Studies for Rural Business and Infrastructure Development, 41(1), 43-61. [Google Scholar] [CrossRef]

Sebastian, V. (2014). Neuromarketing and evaluation of cognitive and emotional responses of consumers to marketing stimuli. Procedia-Social and Behavioral Sciences, 127, 753-757. [Google Scholar] [CrossRef]

Tkachenko, V., Kwilinski, A., Klymchuk, M., \& Tkachenko, I. (2019). The Economic-Mathematical Development Of Buildings Construction Model Optimization On The Basis Of Digital Economy. Management Systems in Production Engineering, 272), 119123. [Google Scholar] [CrossRef]

Quach, S., Thaichon, P., Lee, J. Y., Weaven, S., \& Palmatier R.W. (2019). Toward a theory of outside-in marketing: Past, present, and future. Industrial Marketing Management. [Google Scholar] [CrossRef]

Quinton, S., \& Reynolds, N. (2018). Understanding research in the digital age. Sage. [Google Scholar]

Stanczyk, S. (2016). Triangulacja - laczenie metod badawczych i urzetelnienie badan [Triangulation - combining research methods and research reliability]. In W. Czakon (Ed.), Podstawy metodologii badan w naukach o zarzadzaniu [Fundamentals of research methodology in management sciences](pp. 78-90). Warszawa: Oficyna Wolters Kluwer Business [in Polish].

Thomas, G. (2017). How to do your research project: A guide for students. Sage [Google Scholar]

Vaivio, J., \& Siren, A. (2010). Insights into method triangulation and «paradigms» in interpretive management accounting research. Management Accounting Research, 21(2), 130-141. [Google Scholar] [CrossRef]

Vasylieva, T., Lyeonov, S., Lyulyov, O., \& Kyrychenko, K. (2018). Macroeconomic stability and its impact on the economic growth of the country. Montenegrin Journal of Economics, 14(1), 159-170. [Google Scholar] [CrossRef] 
Venkatesh V., Brown S.A., \& Bala H. (2013). Bridging the qualitative-quantitative divide: Guidelines for conducting mixed methods research in information systems. MIS Ouarterly, 21-54. [Google Scholar]

Webb E.J., Campbell D.T., Schwartz R.D., \& Sechrest, L. (1966). Unobtrusive measures: Nonreactive measures in the social sciences. [Google Scholar]

Zabinski, L. (2006). Paradygmaty nauk spolecznych a ich wykorzystanie w badaniach naukowych systemow zarzadzania marketingowego. Prace Naukowe Akademii Ekonomicznej we Wroclawiu (1107 Badania marketingowe w prestrzeni europejskiej), 17-26. [Google Scholar]

Генрік Двігол, Ph.D., професор, Сілезійський технологічний університет (Польща). Інновації в маркетингових дослідженнях: кількісні та якісні методи аналізу

У статті розглянуто триангуляцію методів та засобів дослідження при оцінюванні маркетингових досліджень. Автором зазначено, що традиційно методологія маркетингових досліджень розподіляється на концептуальні, теоретичні, математичні, емпіричні та формальні методи дослідження, в основі яких лежать кількісні методи, математичні та статистичні моделі. При цьому у маркетингових наукових дослідженнях використовуються концептуальні методи (такі як евтрестичний та креативний) з основним акцентом на аналіз якісних аспектів досліджуваних процесів, дещо посилаючись на емпіричний підхід. Так, методологія емпіричних досліджень широко використовується у маркетингу, що дозволяє розробити емпіричні моделі, завдяки яким можливо виявити, наприклад, реалізовані моделі маркетингових стратегій, що можуть відповідати теоретичним моделям або відрізнятись від них. Автором наголошуено, що емпіричні моделі не завжди можуть бути реалізовані, так як найчастіше посилаються на теперішні або минулі дані. Однак, вищезазначені моделі можуть бути предметом бенчмаркетингу. Більше того, емпіричні моделі сприяють більшій ймовірності концептуальних моделей. Таким чином, подальший розвиток маркетингових досліджень передбачає розширення сфери застосування формальних методів дослідження. Аналіз літературних джерел, свідчить про необхідність поглибленої діагностики комбінованих методів дослідження у процесі дослідження в більш широкому контексті наук про управління. Мета статті виражається наступним питанням: Чи є методологічна триангуляція необхідною умовою науково-дослідницьких процесів при оцінюванні маркетингових досліджень? Автором зазначено, що отримані результати являються частиною комплексного дослідження методів аналізу. Більше того, проведене емпіричне дослідження підтверджує та теоретично доводить, що методологічна тріангуляція $\epsilon$ необхідною умовою для дослідницьких процесів, тоді як перевірка застосовуваних методів, моделей чи процедур $є$ необхідною умовою, яка дозволяє поєднувати науку та практику управління, в той час як методологічна триангуляція підтримує дослідницькі проєкти. Згідно вищезазначеному, автором рекомендовано докласти максимум наукових зусиль, спрямованих на розробку інструментів, методів та процедур для застосування доцільного методу та підходів у рамках маркетингових досліджень, з особливим акцентом на фактори, які визначають якість процесу.

Ключові слова: методи, методи дослідження, маркетингові дослідження, триангуляція, методологія дослідження.

Manuscript received: 29.11.2019.

(C) The author(s) 2020. This article is published with open access at Sumy State University. 